\title{
Influence of the Concentrations of Potassium, Sodium, and Ammonium Ions on the Cesium Sorption with Mixed Nickel Potassium Ferrocyanide Sorbent Based on Hydrated Titanium Dioxide
}

\author{
A. V. Voronina* and V. S. Semenishchev \\ Yeltsin Ural Federal University, ul. Mira 19, Yekaterinburg, 620002 Russia; *e-mail: a.voronina_v@mail.ru
}

Received December 5, 2012

\begin{abstract}
The effect of single-charged cations $\left(\mathrm{Na}^{+}, \mathrm{K}^{+}, \mathrm{NH}_{4}^{+}\right)$on the cesium sorption with mixed nickel potassium ferrocyanide sorbent based on hydrated $\mathrm{TiO}_{2}$ was studied. The $\mathrm{K}^{+}$and $\mathrm{Na}^{+}$ions exert no effect at their concentrations of up to $0.5 \mathrm{M}$; the $\mathrm{Cs}^{+}$distribution coefficients from $\mathrm{KCl}$ and $\mathrm{NaCl}$ solutions are $(1.1 \pm 0.5) \times$ $10^{5}$ and $(8 \pm 3) \times 10^{4} \mathrm{~mL} \mathrm{~g}^{-1}$, respectively. The sorbent is highly specific to $\mathrm{Cs}^{+}$in the presence of ammonium ions. The sorption mechanisms were studied. The concentration ranges in which $\mathrm{Cs}^{+}$and $\mathrm{NH}_{4}^{+}$are sorbed by independent mechanisms $\left(\mathrm{Cs}^{+}\right.$, by the ferrocyanide phase; $\mathrm{NH}_{4}^{+}$, by the phase of hydrated $\left.\mathrm{TiO}_{2}\right)$ and in which the $\mathrm{Cs}^{+}$distribution coefficient decreases owing to competitive filling of the ferrocyanide phase with ammonium ions were determined. At cesium concentrations in solution exceeding $50 \mathrm{mg} \mathrm{L}^{-1}, \mathrm{Cs}^{+}$and $\mathrm{NH}_{4}^{+}$are absorbed jointly owing to coprecipitation in the mixed ferrocyanide phase in the pore space of the sorbent.
\end{abstract}

Keywords: sorption, cesium, ferrocyanide, specificity, selectivity, mechanism

DOI: $10.1134 / \mathrm{S} 1066362213040103$

One of the objectives of modern chemical technology is preparation of selective sorbents capable to recover microcomponents from multicomponent salt solutions (natural or artificial) with the aim, on the one hand, to concentrate and subsequently use the valuable components of the solution and, on the other hand, e.g., to purify natural waters to the environmentally safe level without affecting their salt composition. This problem is also topical for radiochemical technology, namely, for treatment of highly saline liquid radioactive wastes and for recovery of useful individual radionuclides from multicomponent solutions. Therefore, study of the selectivity of the radionuclide sorption is of interest for the development of new sorbents.

The best sorbents for cesium recovery are transition metal ferrocyanides [1]. Their selectivity was studied in numerous works [2-8]. Milyutin [9] reported the separation factors of the $\mathrm{Cs}^{+}-\mathrm{H}^{+}, \mathrm{Cs}^{+}-\mathrm{Na}^{+}, \mathrm{Cs}^{+}-\mathrm{Ca}^{2+}$, and $\mathrm{Cs}^{+}-\mathrm{Mg}^{2+}$ pairs for a wide range of inorganic sorbents including several kinds of ferrocyanides. It was shown that the $\mathrm{Cs}^{+}$sorption with transition metal ferrocyanides is not quite selective and that the selectivity of ferrocyanide sorbents depends on the procedure of their preparation (precipitation followed by granulation, impregnation, preparation of composite sorbents, chemical deposition onto a support). The majority of published papers dealt with the $\mathrm{Cs}^{+}$sorption from solutions containing $\mathrm{Na}^{+}$ions. Data on the selectivity of the $\mathrm{Cs}^{+}$sorption with ferrocyanides in the presence of $\mathrm{K}^{+}$ and $\mathrm{NH}_{4}^{+}$ions are virtually lacking, despite the fact that specifically these ions will exert the strongest effect on the $\mathrm{Cs}^{+}$sorption because of the closeness of their ionic radii to that of $\mathrm{Cs}^{+}$. The affinity series for ferrocyanides can be presented as $\mathrm{Na}^{+}<\mathrm{K}^{+}<\mathrm{NH}_{4}^{+}$.

This study deals with the influence of the $\mathrm{K}^{+}, \mathrm{Na}^{+}$, and $\mathrm{NH}_{4}^{+}$concentrations on the sorption of $\mathrm{Cs}^{+}$with mixed nickel potassium ferrocyanide sorbent based on hydrated $\mathrm{TiO}_{2}$ ( $\mathrm{T}-55$ sorbent). The sorbent preparation procedure is described in [10].

\section{EXPERIMENTAL}

The effect of the $\mathrm{K}^{+}, \mathrm{Na}^{+}$, and $\mathrm{NH}_{4}^{+}$ions on the specificity of T-55 sorbent to $\mathrm{Cs}^{+}$was studied without isotopic carrier (the $\mathrm{Cs}^{+}$concentration is determined by the concentration of the microcomponent, ${ }^{137} \mathrm{Cs}$ ). Batch experiments were performed with ${ }^{137} \mathrm{Cs}$-spiked 

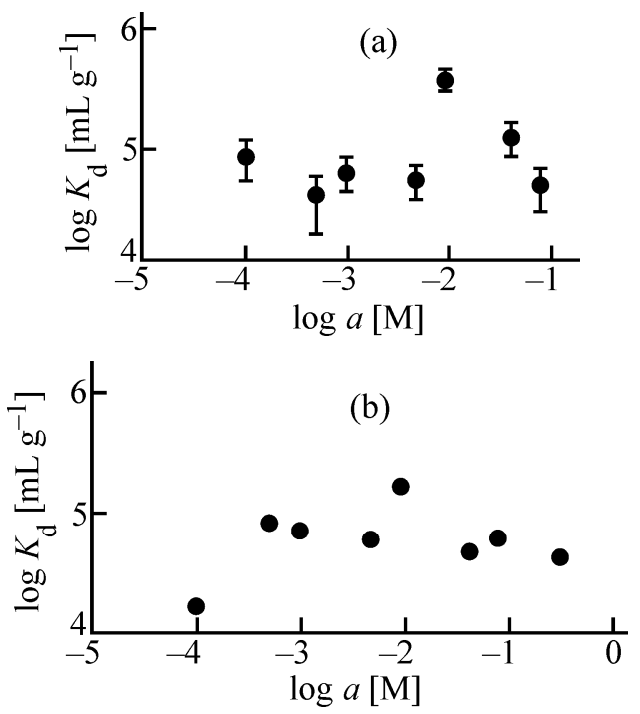

Fig. 1. $\mathrm{Cs}^{+}$distribution coefficient on $\mathrm{T}-55$ sorbent as a function of the activity of single-charged cations. (a) $\mathrm{K}^{+}$ and (b) $\mathrm{Na}^{+}$.

aqueous solutions. The concentrations of the interfering ions were set with $\mathrm{NaCl}, \mathrm{KCl}$, and $\mathrm{NH}_{4} \mathrm{Cl}$ solutions. The active concentration of the cations was varied from $9.88 \times 10^{-5}$ to $0.3 \mathrm{M}$, and the ionic strength, from 0.0001 to $0.5 \mathrm{M}$. The phase contact time was 1 week. Samples were analyzed radiometrically with a UMF-2000 $\alpha, \beta$-radiometer equipped with a semiconductor detector.

Because of the revealed effect of $\mathrm{NH}_{4}^{+}$on the $\mathrm{Cs}^{+}$ recovery with the sorbent, the sorbent specificity to $\mathrm{Cs}^{+}$was additionally studied in a wider range of $\mathrm{NH}_{4}^{+}$ concentrations (up to $2 \mathrm{M}$ ) and at different $\mathrm{Cs}^{+}$concentrations (without isotopic carrier and at $\mathrm{Cs}^{+}$concentrations of $10^{-3}$ and $100 \mathrm{mg} \mathrm{L}^{-1}$ ). The $\mathrm{Cs}^{+}$concentration was set with a $\mathrm{CsCl}$ solution. The choice of $\mathrm{Cs}^{+}$concentrations is associated with the presence of three types of sorption sites in T-55 sorbent [10], characterized by different distribution coefficients of $\mathrm{Cs}^{+}$and different ranges of $\mathrm{Cs}^{+}$concentrations in which these sites realize their capacity, and also with different mechanisms of $\mathrm{Cs}^{+}$sorption. It was of interest to study the selectivity of each kind of sorption sites.

To calculate the activity coefficients $f$ and activities $(a, \mathrm{M})$ of the ions, we used the improved DebyeHückel equation [11]

$$
\log f=A z_{i}^{2} \mu^{1 / 2} /\left(1+a B \mu^{1 / 2}\right),
$$

where $\mu$ is the solution ionic strength; $z_{i}$, ion charge; $A$ and $B$, constants depending on temperature and dielec- tric permittivity of the solvent (for water at $298 \mathrm{~K}, A=$ $0.512, B=0.328$ ); $a$, empirical constant taking into account the ion size and characterizing the mean distance at which the solvated ions approach each other, assuming that they are hard spheres.

The calculated activity coefficients $f$ are well consistent with the tabulated values of the activity coefficients of ions in aqueous solutions at $25^{\circ} \mathrm{C}$ and equal ionic strengths [12].

To study the variation of the selectivity to $\mathrm{NH}_{4}^{+}$in the course of surface modification of hydrated $\mathrm{TiO}_{2}$ (T-5 grade) to obtain mixed nickel potassium ferrocyanide (T-55 sorbent), we obtained isotherms of the $\mathrm{NH}_{4}^{+}$ sorption from $\mathrm{NH}_{4} \mathrm{Cl}$ solutions without $\mathrm{Cs}^{+}$. The ratio of the solution volume to the sorbent weight was $50 \mathrm{~mL} / 75 \mathrm{mg}$. To determine the $\mathrm{NH}_{4}^{+}$concentration in the solution, we used an I-160MI laboratory ion meter equipped with an ELIS-121 $\mathrm{NH}_{4}$ electrode. T-5 sorbent (Thermoxid Research and Production Company) was used in the ammonium form and preliminarily calcined at $400^{\circ} \mathrm{C}$.

We also studied the dependences of the $\mathrm{NH}_{4}^{+}$distribution ratios on the $\mathrm{Cs}^{+}$concentration in the solution. The initial $\mathrm{NH}_{4}^{+}$concentration in the solution was $0.05 \mathrm{M}$. The $\mathrm{Cs}^{+}$concentration was varied from $1 \times$ $10^{-5}$ to $10000 \mathrm{mg} \mathrm{L}^{-1}$. The ratio of the solution volume to the sorbent weight was $50 \mathrm{~mL} / 100 \mathrm{mg}$. T-5 and T-55 sorbents after sorption were examined by IR spectrometry using a Vertex-70 IR-Raman spectrometer with RAM-II attachment (Bruker, Germany).

\section{RESULTS AND DISCUSSION}

A study of the effect of single-charged cations on the $\mathrm{Cs}^{+}$specificity of T-55 sorbent showed that only $\mathrm{NH}_{4}^{+}$cation competed with $\mathrm{Cs}^{+}$in sorption. The logarithm of the $\mathrm{Cs}^{+}$distribution coefficient $\left(\log K_{\mathrm{d}}\right)$ on T-55 sorbent is plotted in Fig. 1 vs. logarithm of the activity $(\log a)$ of $\mathrm{K}^{+}$and $\mathrm{Na}^{+}$ions in solution.

We revealed no effect of $\mathrm{K}^{+}$and $\mathrm{Na}^{+}$ions in the examined concentration range (up to $0.5 \mathrm{M}$ ) on the $\mathrm{Cs}^{+}$ sorption with mixed nickel potassium ferrocyanide sorbent based on hydrated $\mathrm{TiO}_{2}$. The $\mathrm{Cs}^{+}$distribution coefficients determined from $\mathrm{KCl}$ and $\mathrm{NaCl}$ solutions coincide within the uncertainty and amount to $(1.1 \pm$ $0.5) \times 10^{5}$ and $(8 \pm 3) \times 10^{4} \mathrm{~mL} \mathrm{~g}^{-1}$, respectively.

The results we obtained are well consistent with published data on sorption of alkali metal and ammonium ions on transition metal ferrocyanides. As shown 

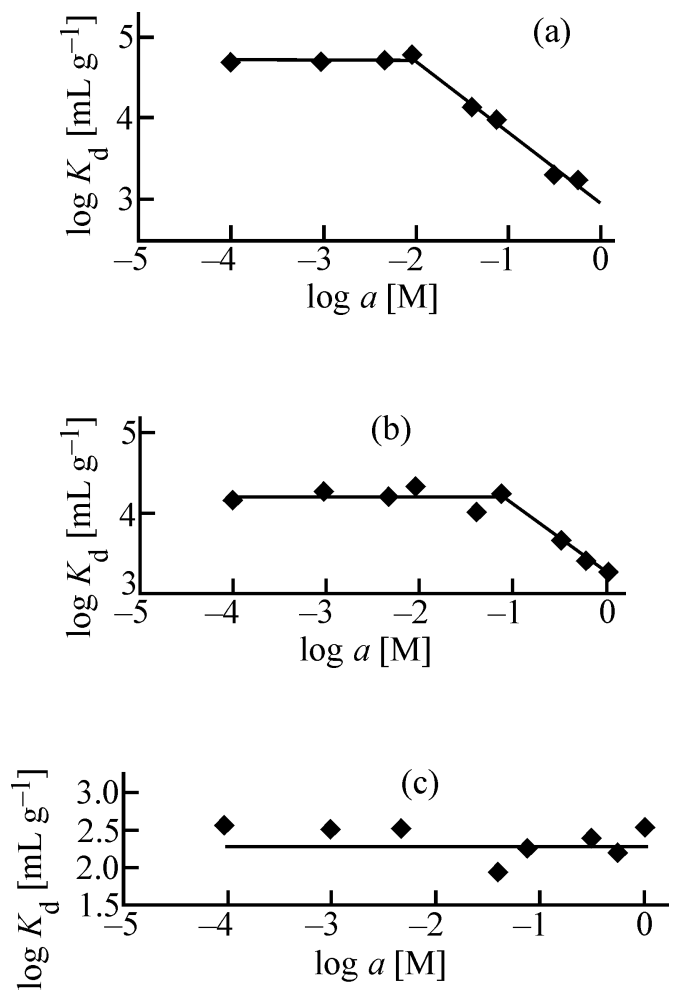

Fig. 2. $\mathrm{Cs}^{+}$distribution coefficient on $\mathrm{T}-55$ sorbent as a function of the activity of $\mathrm{NH}_{4}^{+}$ions in solution. (a) ${ }^{137} \mathrm{Cs}$ without isotopic carrier; $\mathrm{Cs}^{+}$concentration, $\mathrm{mg} \mathrm{L}^{-1}$ : (b) $10^{-3}$ and (c) 100 .

in $[1,13]$, ferrocyanides sorb alkali metal ions owing to the zeolite effect, which is manifested the more strongly, the closer the diameter of the sorbate ion to the channel cross section size in the structure of the ferrocyanide. The maximal zeolite effect is observed for the $\mathrm{Cs}^{+}$cation. The $\mathrm{NH}_{4}^{+}$ion is the closest in size to the $\mathrm{Cs}^{+}$ion (the effective diameter of the hydrated cation is $0.25 \mathrm{~nm}$ for $\mathrm{Cs}^{+}, 0.25 \mathrm{~nm}$ for $\mathrm{NH}_{4}^{+}, 0.3 \mathrm{~nm}$ for $\mathrm{K}^{+}$, and $0.4-0.45 \mathrm{~nm}$ for $\mathrm{Na}^{+}$[12]); therefore, the $\mathrm{NH}_{4}^{+}$ ion exerts a stronger effect on the $\mathrm{Cs}^{+}$sorption than do cations of the other elements under consideration.

Figure 2 shows how the $\mathrm{Cs}^{+}$distribution coefficient on $\mathrm{T}-55$ sorbent depends on the activity of $\mathrm{NH}_{4}^{+}$ions in solution.

Without isotopic carrier, at $\mathrm{NH}_{4} \mathrm{Cl}$ concentrations in solution in the range $0.0001-0.01 \mathrm{M}$, we revealed no effect of $\mathrm{NH}_{4}^{+}$ions on the $\mathrm{Cs}^{+}$sorption. Least-squares processing of points corresponding to higher concentrations of $\mathrm{NH}_{4}^{+}$ions gives a linear regression equation for the correlation between $\log K_{\mathrm{d}}$ and $\log a$. The slope close to unity $(0.9 \pm 0.1)$ suggests that the effective

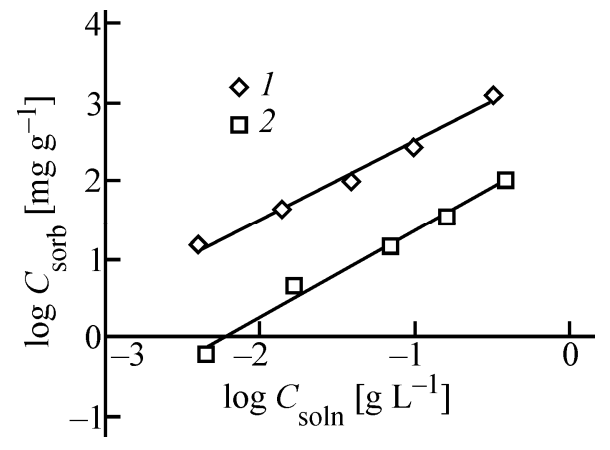

Fig. 3. Isotherms of $\mathrm{NH}_{4}^{+}$sorption from $\mathrm{NH}_{4} \mathrm{Cl}$ solutions with (1) T-5 and (2) T-55 sorbents at $20 \pm 2{ }^{\circ} \mathrm{C}$.
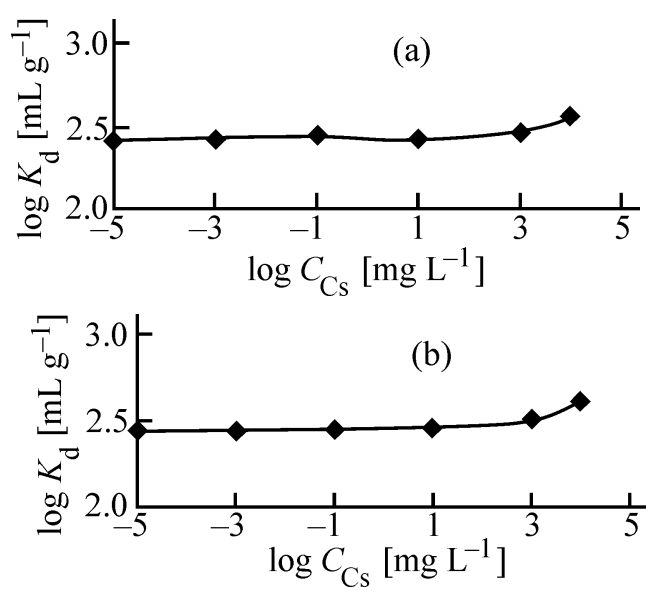

Fig. 4. $\mathrm{NH}_{4}^{+}$distribution coefficient on (a) $\mathrm{T}-5$ and (b) $\mathrm{T}-55$ sorbents as a function of $\mathrm{Cs}^{+}$concentration in solution.

charge of the $\mathrm{Cs}^{+}$ion in the ion-exchange event is close to unity. It was also noted that, at the $\mathrm{Cs}^{+}$concentration in solution of $10^{-3} \mathrm{mg} \mathrm{L}^{-1}, \mathrm{NH}_{4}^{+}$ions started to suppress the $\mathrm{Cs}^{+}$sorption at a concentration higher by an order of magnitude $(0.1 \mathrm{M})$, with the slope also equal to unity within the determination uncertainty. At a $\mathrm{Cs}^{+}$concentration of $100 \mathrm{mg} \mathrm{L}^{-1}$ and, presumably, in the entire concentration range over $50 \mathrm{mg} \mathrm{L}^{-1}$, the $\mathrm{NH}_{4}^{+}$ ions do not affect the $\mathrm{Cs}^{+}$sorption.

Figure 3 shows the isotherms of $\mathrm{NH}_{4}^{+}$sorption from $\mathrm{NH}_{4} \mathrm{Cl}$ solutions with T-5 and T-55 sorbents. Figure 4 shows how the distribution coefficients of $\mathrm{NH}_{4}^{+}$on T-5 and $\mathrm{T}-55$ sorbents depend on the $\mathrm{Cs}^{+}$concentration in solution. The characteristics of the $\mathrm{Cs}^{+}$sorption in the presence of $\mathrm{NH}_{4}^{+}$ions in solution and without them, obtained by statistical processing of the curves, are given in Table 1.

We found that T-5 sorbent is unselective and recovers $\mathrm{NH}_{4}^{+}$with a higher distribution coefficient than $\mathrm{Cs}^{+}$. Presumably, the increased sorbent affinity for $\mathrm{NH}_{4}^{+}$is due to the "memory effect" and to the size of the crys- 
Table 1. Characteristics of $\mathrm{Cs}^{+}$and $\mathrm{NH}_{4}^{+}$sorption from $\mathrm{NH}_{4} \mathrm{Cl}$ solutions with $\mathrm{T}-5$ and $\mathrm{T}-55$ sorbents

\begin{tabular}{|c|c|c|c|c|}
\hline \multirow[b]{2}{*}{ Sorbent } & \multicolumn{2}{|c|}{$\mathrm{Cs}^{+}$sorption } & \multicolumn{2}{|c|}{$\mathrm{NH}_{4}^{+}$sorption $^{+}$} \\
\hline & $\begin{array}{l}{\left[\mathrm{Cs}^{+}\right] \text {in solution, }} \\
\mathrm{mg} \mathrm{L}^{-1}\end{array}$ & $\log K_{\mathrm{d}}$ of $\mathrm{Cs}^{+}\left[\mathrm{mL} \mathrm{g}^{-1}\right]$ & $\begin{array}{c}\log K_{\mathrm{d}} \text { of } \mathrm{NH}_{4}^{+} \text {without } \mathrm{Cs}^{+} \\
{\left[\mathrm{mL} \mathrm{g}^{-1}\right]}\end{array}$ & $\begin{array}{c}\log K_{\mathrm{d}} \text { of } \mathrm{NH}_{4}^{+} \text {in the presence } \\
\text { of } \mathrm{Cs}^{+}\left[\mathrm{mL} \mathrm{g}^{-1}\right]\end{array}$ \\
\hline $\mathrm{T}-5$ & $\begin{array}{c}10^{-7}-10 \\
10-1000\end{array}$ & $\begin{array}{c}1.8 \pm 0.5 \\
\sim 1\end{array}$ & $3.6 \pm 0.1$ & $2.5 \pm 0.1$ \\
\hline $\mathrm{T}-55$ & $\begin{array}{c}2 \times 10^{-7}-5 \times 10^{-4} \\
5 \times 10^{-3}-5 \\
50-500\end{array}$ & $\begin{array}{l}4.8 \pm 0.2 \\
4.2 \pm 0.1 \\
2.3 \pm 0.2\end{array}$ & $2.5 \pm 0.1$ & $2.5 \pm 0.1$ \\
\hline
\end{tabular}

tal lattice of hydrated $\mathrm{TiO}_{2}$, formed in the course of the synthesis. The procedure used for preparing T-5 sorbent yields the sorbent in the ammonium form. On calcining the sorbent at $400^{\circ} \mathrm{C}$, the ammonia is removed, but on contact with an $\mathrm{NH}_{4} \mathrm{Cl}$ solution the $\mathrm{NH}_{4}^{+}$ion in the presence of which the sorbent structure was formed tends to occupy its site. Similar effects were noted in [14] where it was shown that silica gels primarily sorbed the substance that had been initially present in the reaction mixture in the course of the synthesis.

Figure 5 shows the IR spectra of T-5 and T-55 sorbents after the sorption from solutions containing $0.05 \mathrm{M} \mathrm{NH}_{4}^{+}$and $10^{-4} \mathrm{mg} \mathrm{L}^{-1}$ and $10 \mathrm{~g} \mathrm{~L}^{-1} \mathrm{Cs}^{+}$. The IR spectra of all the sorbents contain a broad absorption band at $2800-3800 \mathrm{~cm}^{-1}$, characteristic of stretching vibrations of the $\mathrm{OH}$ groups of titanium hydroxide, participating in hydrogen bonding. The strong absorption peak at $1635 \mathrm{~cm}^{-1}$ is due to bending vibrations of adsorbed water molecules. T-55 sorbent also exhibits

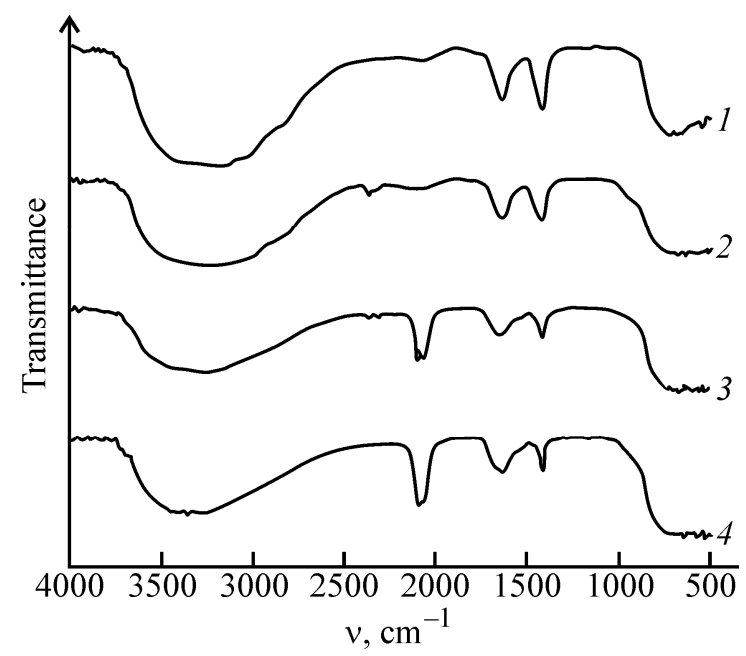

Fig. 5. IR spectra of sorbents after $\mathrm{NH}_{4}^{+}$sorption from $0.05 \mathrm{M} \mathrm{NH}_{4}^{+}$solutions with different $\mathrm{Cs}^{+}$concentrations. Sorbent: $(1,2) \mathrm{T}-5$ and $(3,4) \mathrm{T}-55 . \mathrm{Cs}^{+}$concentration: $(1,3) 10^{-4} \mathrm{mg} \mathrm{L}^{-1}$ and $(2,4) 10 \mathrm{~g} \mathrm{~L}^{-1}$. absorption bands at 2060 and $2092 \mathrm{~cm}^{-1}$, characteristic of the ferrocyanide phase. In the IR spectra of T-5 and $\mathrm{T}-55$ sorbents after sorption from $0.05 \mathrm{M} \mathrm{NH}_{4}^{+}$solution, irrespective of the chosen $\mathrm{Cs}^{+}$concentration, there are absorption peaks in the region of $1400 \mathrm{~cm}^{-1}$, corresponding to $\mathrm{N}-\mathrm{H}$ bonds in the $\mathrm{NH}_{4}^{+}$ions, which also confirms the $\mathrm{NH}_{4}^{+}$uptake by the sorbents.

As compared to T-5 sorbent, T-55 sorbent is highly specific to $\mathrm{Cs}^{+}$in the presence of $\mathrm{NH}_{4}^{+}$(Table 1). The results we obtained suggest that the sorption of $\mathrm{Cs}^{+}$ and $\mathrm{NH}_{4}^{+}$with $\mathrm{T}-55$ sorbent in a definite concentration range occurs by different mechanisms, and therefore the $\mathrm{Cs}^{+}$distribution coefficient is independent of the $\mathrm{NH}_{4}^{+}$concentration (Figs. 2, 4). At $\mathrm{Cs}^{+}$concentrations in solution of up to $50 \mathrm{mg} \mathrm{L}^{-1}$ and $\mathrm{NH}_{4}^{+}$concentrations of up to 0.01 and $0.1 \mathrm{M}$, the $\mathrm{NH}_{4}^{+}$ions are sorbed by sorption sites of hydrated $\mathrm{TiO}_{2}$ :

$$
\equiv \mathrm{TiO}-\mathrm{H}^{+}+\mathrm{NH}_{4}^{+} \rightleftarrows \equiv \mathrm{TiO}-\mathrm{NH}_{4}^{+}+\mathrm{H}^{+},
$$

whereas $\mathrm{Cs}^{+}$is sorbed by sites of the ferrocyanide phase:

$$
\begin{aligned}
& \equiv \mathrm{TiO}-\mathrm{Ni} \backslash \quad \equiv \mathrm{TiO}-\mathrm{Ni} \text { । }
\end{aligned}
$$

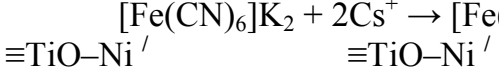

$$
\begin{aligned}
& \left.\left.\equiv \mathrm{TiO}_{-\mathrm{Ni}} / \mathrm{CN}\right)_{6}\right] \mathrm{Cs}_{2}+2 \mathrm{~K}^{+} \text {, } \\
& \mathrm{K}_{2}(\mathrm{TiO})\left[\mathrm{Fe}(\mathrm{CN})_{6}\right]+2 \mathrm{Cs}^{+} \rightarrow \mathrm{Cs}_{2}(\mathrm{TiO})\left[\mathrm{Fe}(\mathrm{CN})_{6}\right]+2 \mathrm{~K}^{+}
\end{aligned}
$$

With an increase in the $\mathrm{NH}_{4}^{+}$concentration in the solution, the sorption sites of hydrated $\mathrm{TiO}_{2}$ becomes filled, and $\mathrm{NH}_{4}^{+}$starts to compete with $\mathrm{Cs}^{+}$for filling of sorption sites of the ferrocyanide phase:

$$
\begin{array}{ll}
\equiv \mathrm{TiO}-\mathrm{Ni}{ }_{\backslash} & \equiv \mathrm{TiO}-\mathrm{Ni}{ }_{\backslash} \\
\left.\qquad \mathrm{Fe}(\mathrm{CN})_{6}\right] \mathrm{K}_{2}+\underset{2}{2} & \mathrm{NH}_{4}^{+} \rightarrow\left[\mathrm{Fe}(\mathrm{CN})_{6}\right]\left(\mathrm{NH}_{4}\right)_{2}+2 \mathrm{~K}^{+}, \\
\equiv \mathrm{TiO}-\mathrm{Ni}^{\prime} & \equiv \mathrm{TiO}-\mathrm{Ni}^{\prime}
\end{array}
$$

$\mathrm{K}_{2}(\mathrm{TiO})\left[\mathrm{Fe}(\mathrm{CN})_{6}\right]+2 \mathrm{NH}_{4}^{+} \rightarrow\left(\mathrm{NH}_{4}\right)_{2}(\mathrm{TiO})\left[\mathrm{Fe}(\mathrm{CN})_{6}\right]+2 \mathrm{~K}^{+}$ 
Table 2. Static exchange capacities (SECs) of sorption sites of T-5 and T-55 sorbents for $\mathrm{Cs}^{+}$, determined in tap water with $\mathrm{pH} 7.8 \pm 0.2$ [the content of hardness salts, alkali metals, and anions in tap water met SanPiN (Sanitary Rules and Regulations) 2.1.4.1074-01; the total hardness was 2.4 mg-equiv $\mathrm{L}^{-1}$, and the $\mathrm{Ca}^{2+}$ concentration was $30 \pm$ $\left.5 \mathrm{mg} \mathrm{L}^{-1}\right]$

\begin{tabular}{l|l|c}
\hline Sorbent & \multicolumn{1}{|c|}{ Sorption site } & SEC of site, $\mathrm{m} \mathrm{L}^{-1}$ \\
\hline $\mathrm{T}-5$ & $\mathrm{H}_{3} \mathrm{O}^{+}$ & 0.1 \\
& $\mathrm{OH}^{-}$ & $\geq 20$ \\
\hline \multirow{3}{*}{$\mathrm{T}-55$} & $\mathrm{~K}_{2} \mathrm{Ni}\left[\mathrm{Fe}(\mathrm{CN})_{6}\right]$ & 0.001 \\
& $\begin{array}{l}\mathrm{K}_{2}(\mathrm{TiO})\left[\mathrm{Fe}(\mathrm{CN})_{6}\right] \\
\mathrm{OH} \text { and } \mathrm{Cs}_{2} \mathrm{Ni}\left[\mathrm{Fe}(\mathrm{CN})_{6}\right] \text { de- } \\
\text { posited in the pore space of } \\
\text { the sorbent }\end{array}$ & 255 \\
\hline
\end{tabular}

Difference between Figs. $2 \mathrm{a}$ and $2 \mathrm{~b}$ in the $\mathrm{NH}_{4}^{+}$concentration at which the competition becomes noticeable may be due to different specificities and capacities of the sorption sites (Table 2) in different concentration ranges.

At high cesium concentrations in solution, the presumable mechanism of the $\mathrm{Cs}^{+}$sorption with T-55 sorbent is deposition of poorly soluble nickel cesium ferrocyanide in the sorbent pores, rather than the ion exchange. In the presence of $\mathrm{NH}_{4}^{+}$in the solution, $\mathrm{Cs}^{+}$ and $\mathrm{NH}_{4}^{+}$can coprecipitate in the form of mixed ferrocyanides.

Thus, T-55 sorbent is highly specific to $\mathrm{Cs}^{+}$in the presence of single-charged $\mathrm{Na}^{+}, \mathrm{K}^{+}$, and $\mathrm{NH}_{4}^{+}$cations and can be efficient for treatment of highly saline liquid radioactive wastes. Studies showed that the concentration of $\mathrm{Na}^{+}$and $\mathrm{K}^{+}$ions does not affect the $\mathrm{Cs}^{+}$ sorption. In definite ranges of $\mathrm{Cs}^{+}$and $\mathrm{NH}_{4}^{+}$concentrations $\left(2 \times 10^{-7}-5 \times 10^{-4} \mathrm{mg} \mathrm{L}^{-1}\right.$ and up to $0.01 \mathrm{M} ; 5 \times$ $10^{-3}-5 \mathrm{mg} \mathrm{L}^{-1}$ and up to $0.1 \mathrm{M}$, respectively), $\mathrm{NH}_{4}^{+}$ ions do not affect the $\mathrm{Cs}^{+}$sorption, and $\mathrm{Cs}^{+}$and $\mathrm{NH}_{4}^{+}$ are sorbed by different mechanisms. At higher concentrations of the components, the $\mathrm{NH}_{4}^{+}$ion, which, as compared with $\mathrm{Na}^{+}$and $\mathrm{K}^{+}$ions, is closer to $\mathrm{Cs}^{+}$in the ionic radius, competes with $\mathrm{Cs}^{+}$in sorption, which leads to a decrease in the $\mathrm{Cs}^{+}$distribution coefficient. At $\mathrm{Cs}^{+}$concentration in solution exceeding $50 \mathrm{mg} \mathrm{L}^{-1}$, $\mathrm{Cs}^{+}$and $\mathrm{NH}_{4}^{+}$are taken up jointly owing to coprecipitation in the form of mixed ferrocyanides in the pore space of the sorbent.

\section{ACKNOWLEDGMENTS}

The study was financially supported by the Ministry of Education and Science of the Russian Federation within the framework of Federal Target Program "Scientific and Scientific-Pedagogical Personnel of Innovative Russia" for the years 2009-2013 (agreement no. 14.A18.21.0313).

\section{REFERENCES}

1. Tananaev, I.V., Seifer, G.B., Kharitonov, Yu.Ya., et al., Khimiya ferrotsianidov (Chemistry of Ferrocyanides), Moscow: Nauka, 1971.

2. Bardov, A.I., Voroshilov, Yu.A., Zemlina, N.P., et al., Radiokhimiya, 1999, vol. 41, no. 5, pp. 451-455.

3. Sharygin, L.M. and Muromskii, A.Yu., At. Energ., 2000, vol. 89, no. 2, pp. 146-150.

4. Avramenko, V.A., Zheleznov, V.V., Sokol'nitskaya, T.A., et al., Sorbts. Khromatogr. Protsessy, 2006, vol. 6, no. 6, pp. 899-904.

5. Kopyrin, A.A., Pyartman, A.K., Keskinov, V.A., et al., Radiokhimiya, 1999, vol. 41, no. 3, pp. 236-238.

6. Sharygin, L.M., Muromskii, A.Yu., Moiseev, V.E., and Tsekh, A.R., Zh. Prikl. Khim., 1996, vol. 77, no. 12, pp. 2009-2013.

7. Orechovska, J. and Rajec, P., J. Radioanal. Nucl. Chem., 1999, vol. 242, no. 2, pp. 387-390.

8. Kazemian, H., Zakeri, H., and Rabbani, M.S., J. Radioanal. Nucl. Chem., 2006, vol. 268, no. 2, pp. 231-236.

9. Milyutin, V.V., Doctoral (Chem.) Dissertation, Moscow: Frumkin Inst. of Physical Chemistry and Electrochemistry, Russian Acad. Sci., 2008.

10. Voronina, A.V., Semenishchev, V.S., Nogovitsyna, E.V., and Betenekov, N.D., Radiokhimiya, 2012, vol. 54 , no. 1 , pp. 66-70.

11. Peters, D.G., Hayes, J.M., and Hieftje, G.M., Chemical Separations and Measurements; Theory and Practice of Analytical Chemistry, Philadelphia: Saunders, 1974.

12. Zolotov, Yu.A., Dorokhova, E.N., Fadeeva, V.I., et al., Osnovy analiticheskoi khimii: Uchebnik dlya vuzov (Fundamentals of Analytical Chemistry: Textbook for Higher Schools), book 1: Obshchie voprosy. Metody razdeleniya (General Problems. Separation Methods), Moscow: Vysshaya Shkola, 1999, 2nd ed.

13. Vol'khin, V.V., Kolesova, S.A., et al., Zh. Neorg. Khim., 1971, vol. 16, pp. 1611-1613.

14. Belyakova, L.A., in Adsorbtsiya $i$ adsorbenty: Respublikanskii mezhvedomstvennyi sbornik nauchnykh trudov (Adsorption and Adsorbents: Republican Interdepartmental Coll. of Scientific Works), Kiev: Naukova Dumka, 1982, no. 10, pp. 59-64. 